\title{
Pre-Service Lower Secondary School Mathematics Teachers' Ability of Drawing the Symmetry of a Figure according to a Line
}

\author{
Ebru Mutlu ${ }^{1, *}$ and Asuman Duatepe-Paksu ${ }^{1}$ \\ ${ }^{1}$ Department of Mathematics and Science Education, Pamukkale University, Turkey
}

\begin{abstract}
The aim of the present study is to investigate pre-service lower secondary school mathematics teachers' ability of drawing a given figure's symmetry according to the lines in various positions. The sampling of the study comprised eight pre-service mathematics teachers who were attending a mathematics education department and willing to participate in the study. The criterion sampling methods was used. Six open-ended questions were asked to determine the ability of the prospective teachers to take the symmetry of a given figure according to the lines in different situations. Furthermore, interviews were conducted with the participants on their definitions of symmetry and symmetry according to a line. The data of the study were the prospective teachers' drawing papers and the video recordings of the interviews including the definitions of the concepts of symmetry and symmetry according to a line. Content analysis was used to analyze the data. The findings indicated that the prospective teachers were successful in drawing the symmetry of a given figure according to the vertical, horizontal and oblique lines, and they used an informal language to define the concepts of symmetry and symmetry according to a line.
\end{abstract}

\section{Introduction}

One of the aims of the mathematics curriculum at primary education is to train individuals who can understand mathematics and use it in daily life. This fact has been emphasized for teaching mathematics to use the new curriculum which has been prepared by focusing on the national and international research studies, mathematics curriculum of developed countries and the experiences of mathematics education in our country (MoNE, 2018).

It is evident in the related literature that many different terms are used to express the difficulties in mathematics learning. The terms "difficulty" and "mistakes" are the terms most often used by the students to express the difficulties they have experienced in learning mathematics (Aksoy and Bayazit, 2010). Students, teacher candidates and teachers are faced with many difficulties regarding many concepts specific to mathematics. Some of these studies focus on the concept of 'symmetry' (Köse, 2012, Aktaş, 2015). Since the concept of symmetry is interwoven with the real life, it is one of the fundamental issues for the students to get prepared for the life. In mathematics, the concept of symmetry is

* Corresponding author: emutlu@pau.edu.tr 
intertwined with nature (Dreyfus \& Eisenberg, 1989). Studies in the literature on symmetry are generally conducted on students, and they aim to determine their current knowledge and misconceptions (Köse 2012, Karadeniz et. al 2015). There is a limited research on what pre-service mathematics teachers pay attention when taking the symmetry according to a line, and on determining their existing misconceptions. The purpose of this study is to reveal the existing misconceptions of pre-service teachers regarding the concept of reflection symmetry.

\section{Aim of the Study}

The aim of the current study is to find out how pre-service primary school mathematics teachers define symmetry and their knowledge about drawing the symmetry of a figure according to a given symmetry line. In response to this general objective, answers to the following questions are investigated.

Sub-questions:

1-) How is the ability of pre-service secondary school mathematics teachers in taking the symmetry of a given shape according to the horizontal, vertical and oblique lines when the shape cuts the symmetry line or not?

2-) How do the pre-service secondary school mathematics teachers define the concepts of 'symmetry' and 'according to straight line'?

\section{Method}

In this study, which aims at determining the pre-service mathematics teachers' definitions of the 'symmetry' and 'symmetry according to the straight line' concepts. A case study design of qualitative research methods was used in collecting, analyzing and interpreting the data obtained from the participants.

\subsection{Participants of the Study}

The sampling of the study consists of eight senior pre-service mathematics teachers (5 females and 3 males), who are attending a mathematics education department in the study. The aim of selecting final year prospective teachers is that they are considered to have the attainments regarding the concepts of symmetry and reflection symmetry in geometry lessons. The average geometry course grade of the participants' is 85 and above. The criterion sampling method, which is non-probabilistic method was used to choose the participants.

\subsection{Data Collection}

Six open-ended questions were used to determine the ability of prospective teachers to take the symmetry of a figure according to the vertical, horizontal and oblique lines for two cases whether the figure intersect or does not intersects with the line (Figure 1). Subsequently, interviews were held on the candidates' definitions of the concepts of 'symmetry' and 'symmetry according to a line". The data of the study were collected through one-to-one interview method. Each interview with the participants took approximately 30 minutes and they were recorded. In this way, the meanings that the prospective teachers attributed to the idea of taking the symmetry of an object are elaborated. A semi-structured interview method inspired from Köse (2012) was created. Expert opinions were also collected to form the interview questions. 


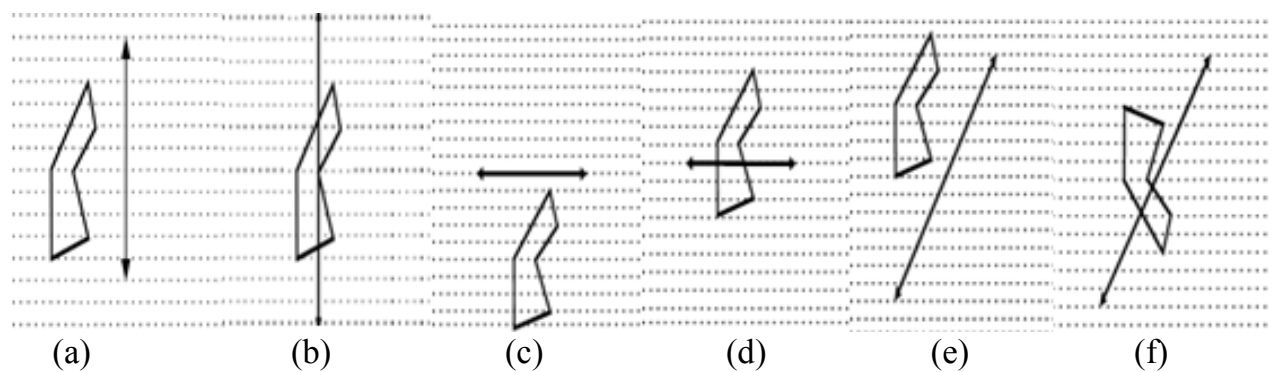

Fig.1. A figure's intersecting and not intersecting of a line in a horizontal, vertical and oblique position

\subsection{Data Analysis}

In the analysis of the data, the following four categories adapted by Lima (2006; as cited in Köse, 2012) were utilized to take the symmetry of a given shape according to a line: 1. Completely correct drawing, 2. Partially correct drawing, 3. Wrong drawing, 4. Blank or incomplete drawing.

\section{Findings}

Some examples of pre-service mathematics teachers drawing of the symmetry of the figures according to lines in vertical, horizontal and oblique positions are shown in Fig 2-4. Fig 2 shows the completely correct drawing of symmetry according to vertical line drawn by preservice teachers 2 (PT2). Fig 3 shows the partially correct drawing of symmetry according to horizontal line drawn by PT6. Fig 4 shows the wrong drawing of symmetry according to oblique line drawn by PT4.

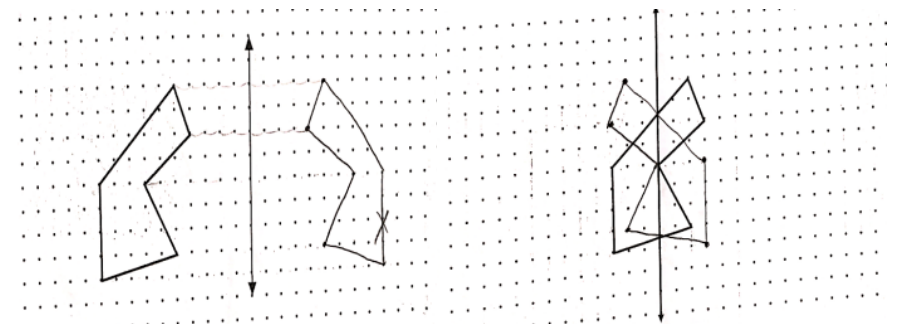

Fig.2. Completely correct drawing of symmetry drawn by PT2 according to vertical line

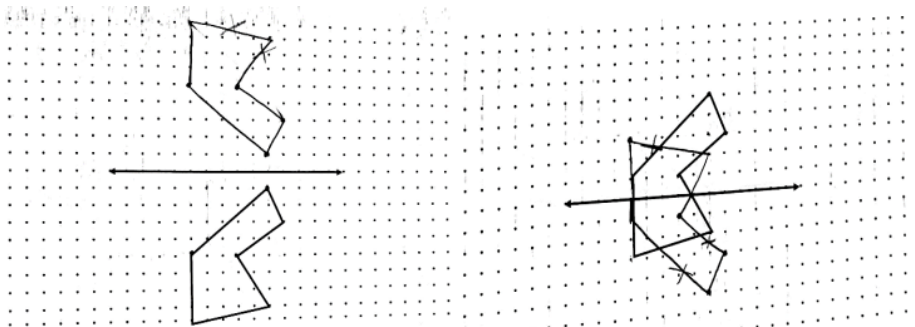

Fig.3. Partially correct drawing of symmetry drawn by PT6 according to horizontal line 


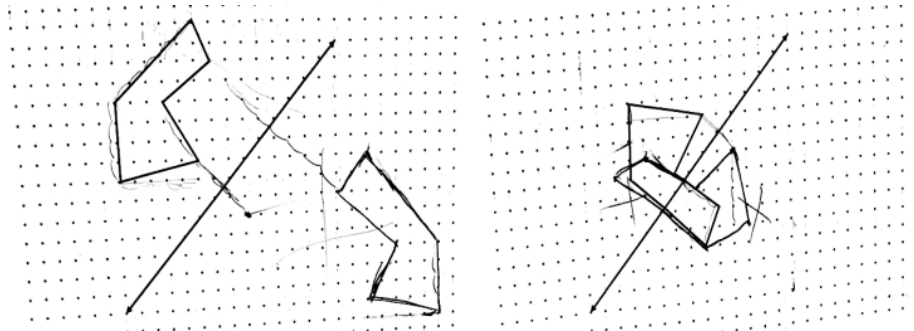

Fig.4. Wrong drawing of symmetry drawn by PT4 according to oblique line

Table 1 shows the answers of pre-service mathematics teachers to six open-ended questions regarding figures given in Figure 1.

Table 1. The frequency and percentage of responses of teacher candidates to the question of taking the symmetry of a figure according to a line in vertical, horizontal and oblique positions $[\mathrm{f}(\%)]$

\begin{tabular}{lcccc}
\hline Figures & Completely correct & Partially correct & Wrong & Blank or incomplete \\
\hline Figure 1(a) & $7(87.5)$ & $1(12.5)$ & $0(0)$ & $0(0)$ \\
Figure 1(b) & $7(87.5)$ & $1(12.5)$ & $0(0)$ & $0(0)$ \\
Figure 1(c) & $5(62.5)$ & $3(37.5)$ & $0(0)$ & $0(0)$ \\
Figure 1(d) & $2(25)$ & $6(75)$ & $0(0)$ & $0(0)$ \\
Figure 1(e) & $4(50)$ & $2(25)$ & $2(25)$ & $0(0)$ \\
Figure 1(f) & $5(62.5)$ & $3(37.5)$ & $0(0)$ & $0(0)$ \\
\hline
\end{tabular}

The definitions of the pre-service mathematics teachers regarding the symmetry concept are given in Table 2. For instance, pre-service teacher 5 (PT5) defined the symmetry concept as "By taking according to that line, it is crossing over a certain point or any object."

Table 2. Participants' definitions regarding the symmetry concept

\begin{tabular}{lcc}
\hline Definitions & Frequency & Pre-service Teacher (PT) \\
\hline Mirror image & 1 & PT1 \\
Reflection & 2 & PT2, PT7 \\
Equidistance & 1 & PT4 \\
Mirror image and reflection & 1 & PT5 \\
Equidistance and reflection & 1 & PT8 \\
Equidistance and mirror image & 2 & PT3, PT6 \\
\hline
\end{tabular}

Definitions of the pre-service teachers regarding the concept of symmetry according to a line are given in Table 3. For instance, pre-service teacher 2 (PT2) defined the symmetry according to a line as "Symmetry according to the line is the co-image of a line on the other side of the line, the shortest distance of a point to the point on that line."

Table 3 Participants' definitions regarding the concept of symmetry according to a line

\begin{tabular}{lcc}
\hline Definitions & Frequency & Pre-service Teacher (PT) \\
\hline Reflection & 4 & PT3, PT4, PT6, PT7 \\
Co-image & 1 & PT2 \\
Equal distance image & 2 & PT1, PT8 \\
Crossing over & 1 & PT5 \\
\hline
\end{tabular}


Based on the findings of the study, there are some variations on the ability of fourth grade pre-service secondary school mathematics teachers to take the symmetry of a given figure according to a line in different positions. The findings of the present study are in line with those of a study conducted by Karadeniz et. al. (2015) on prospective teachers. When the answers given by the prospective teachers were examined, it is clear that they were the most successful at the question about taking the symmetry of a given figure according to a vertical line. On the other hand, they had the lowest success at the question including a figure's intersecting and not intersecting of an oblique line.

It was found that the teacher candidates used one or more of the terms of reflection, mirror, equidistance, co-image in their expressions to explain the concept of symmetry and symmetry according to a straight line. When the definitions were examined, it was seen that the teacher candidates used an informal language. Teacher candidates' use of that informal language to express the symmetry concept similar with the findings of the study of Kose (2012) on the 8th grade students. It is noteworthy that the data obtained from the current research sampling are similar with those of the 8th grade students. Only one teacher candidate tried to explain the concepts of symmetry and symmetry according to a line by using correct mathematical expressions. However, he could not make an appropriate definition. In this context, it can be also considered that the participating teacher candidates may not have efficient language skills.

\section{Conclusion and Implication}

Based on the analysis of the research data, it can be said that prospective teachers are generally successful in their skills to take the symmetry of a given figure according to the different cases of a line in contrast to the findings in the literature (Köse, 2012). This is thought to be due to the sampling of the study which consists of $4^{\text {th }}$ grade pre-service mathematics teachers. It can be said that they are likely to be more successful when they consider the basic components while taking symmetry according to a straight line. According to the findings of the Aktas's study (2015), the achievements of pre-service teachers can be further increased by using dynamic geometry software to take the symmetry of a figure according to a line in each case. Considering that teacher candidates have taken geometry and geometry teaching courses, it can be anticipated that these courses may have affected their ability of taking symmetry.

Moreover, given the definitions of the pre-service teachers regarding the concepts of symmetry and the symmetry according to a line, it is concluded that they cannot use mathematical expressions efficiently when making the definitions. For the development of teacher candidates' skills of definition, topics including activities to enhance that skill can be involved in the course contents taken during undergraduate education.

Studies can be conducted with a broader sample group for undergraduate students and in technology-supported settings. It is especially considered that the studies to measure the pre-service teachers' skills of definition or to develop these skills will also contribute to the existing literature. It is thought that the pre-service teachers who will graduate from the education faculties should be supported with activities including verbal skills along with mathematical skills.

\section{References}


1. Aksoy, Y. ve Bayazit, İ. (2010). Simetri kavramının öğrenim ve öğretiminde karşılaşılan zorlukların analitik bir yaklaşımla incelenmesi. E. Bingölbali and M. F. Özmantar (Eds.), İlköğretimde karşılaşılan matematiksel zorluklar ve çözüm önerileri içinde (2. Bask1., s. 187-215). Ankara: Pegem Akademi.

2. Aktaş, M. (2015). 7.Sınıf matematik dersinde bilgisayar animasyonları ve aktiviteleri ile simetri öğretiminin akademik başarıya etkisi. GEFAD / GUJGEF 35(1): 49-62

3. Dreyfus, T., \& Eisenberg, T. (1989). Symmetry in mathematics learning. zentralblatt fur didaktik der mathematik. 90(2), 53-59.

4. Karadeniz, M.H., Baran, T., Bozkuş, F. \& Gündüz, N. (2015). İlköğretim Matematik Öğretmeni Adaylarının Yansıma Simetrisi ile İlgili Yaşadıkları Zorluklar. Turkish Journal of Computer and Mathematics Education. Vol.6 No.1, 117-138.

5. Köse, N.Y. (2012).İlköğretim öğrencilerinin doğruya göre simetri bilgileri. Hacettepe University Journal of Education Faculty, 42: 274-286.

6. Ministry of National Education [MoNE]. (2018). 6-8th grade primary school mathematics course curriculum. Board of Education and Discipline.

7. National Council of Teachers of Mathematics [NCTM]. (2000). Principles and Standards for School Mathematics. Reston, VA. 